\title{
PENINGKATAN KEMAMPUAN PROBLEM SOLVING MAHASISWA SEBAGAI CALON GURU FISIKA MENGGUNAKAN SOCRATIC DIALOGUE
}

\author{
Nurita Apridiana Lestari \\ Jurusan Fisika, FMIPA, Universitas Negeri Surabaya, Indonesia
}

\begin{abstract}
Mastery of the concepts of physics students can be measured by its ability to solve the problems ofphysics. Problem solving ability is one component that must be owned by the students as a physics teacher candidates. Based on the results of initial observations, it is known that the problem solving ability of students is still low, especially associated with the use of physics concepts to solve problems. Therefore, the ability of problem solving should be trained in teaching as a form of scaffolding for students. Scaffolding can be done through the method of Socratic dialogue which is the provision of structured questions to help students find answers to the problems of physics using the right concept. This type of research is the Classroom Action Research with two cycles were performed on physics student teachers in the subjects Physics 1 with a fluid material. Improved problem solving ability was measured using test items at the end of the cycle. The results qualitatively show their developments and increased activity in the classroom compared to learning before the action. These results are supported quantitatively by an increase in average test scores of the first cycle of 70.00 into 75.86 in the second cycle.
\end{abstract}

Keywords: problem solving, socratic dialogue

\section{Abstrak}

Penguasaan konsep fisika mahasiswa dapat diukur dari kemampuannya dalam memecahkan permasalahan fisika (problem solving). Kemampuan problem solving merupakan salah satu komponen yang harus dimiliki oleh mahasiswa sebagai calon guru fisika. Berdasarkan hasil observasi awal, diketahui bahwa kemampuan problem solving mahas is wa masih rendah, khususnya terkait dengan penggunaan konsep fisika untuk memecahkan masalah. Oleh karena itu, kemampuan problem solving perlu dilatihkan dalam pembelajaran sebagai bentuk scaffolding bagi mahasiswa. Scaffolding dapat dilakukan melalui metode socratic dialogue yang merupakan pemberian pertanyaan terstruktur untuk membantu mahasiswa menemukan jawaban permasalahan fisika menggunakan konsep yang tepat. Jenis penelitian ini adalah Penelitian Tindakan Kelas (PTK) dengan 2 siklus yang dilakukan pada mahasiswa calon guru fisika pada matakuliah Fisika Dasar 1 dengan materi Fluida. Peningkatan kemampuan problem solving diukur menggunakan butir soal tes di akhir siklus. Hasil penelitian secara kualitatif menunjukkan adanya perkembangan dan peningkatan aktivitas di kelas dibandingkan dengan pembelajaran sebelum adanya tindakan. Hasil tersebut didukung secara kuantitatif melalui peningkatan rata-rata nilai tes dari siklus I sebesar 70,00 menjadi 75,86 pada siklus II.

Kata Kunci: problem solving, socratic dialogue

DOI : http://dx.doi.org/10.21067/mpej.v1i1.1627

Diterima: Januari 2017; Disetujui: Maret 2017

\section{PENDAHULUAN}

Sebagai Lembaga Pendidik dan

\footnotetext{
* Corresponding Author:

nuritalestari@unesa.ac.id
}

Tenaga Kependidikan (LPTK), Universitas Negeri Surabaya memiliki tujuan untuk mencetak calon guru yang berpotensi. Berpotensi baik dalam bidang pendidikan 
maupun keilmuan. Khususnya pada Program Studi Pendidikan Fisika, mahasiswa sebagai calon guru fisika diharapkan memiliki kompetensi sesuai dengan Pasal 10 ayat (1) UUGD Nomor 14 tahun 2005. Kompetensi yang harus dimiliki meliputi kompetensi pedagogik, kompetensi kepribadian, kompetensi sosial, dan kompetensi profesional. Terkait dengan kompetensi profesional bagi seorang guru, mahasiswa diharapkan dapat menguasai materi fisika dengan baik. Hal ini disebabkan mahasiswa akan menjadi guru yang mengajarkan materi-materi fisika tersebut kepada peserta didik, khususnya tingkat menengah. Oleh karena itu, diupayakan materi fisika dapat diajarkan dengan terstruktur dan tidak terjadi kesalahan pemahaman konsep.

Salah satu matakuliah yang bertujuan untuk memfokuskan mahasiswa pada penguasaan materi fisika yaitu Fisika Dasar. Berdasarkan hasil observasi awal terhadap mahasiswa program studi pendidikan fisika angkatan 2013, diketahui bahwa nilai rata-rata matakuliah Fisika Dasar adalah 68. Data diambil dari hasil Ujian Akhir Semester (UAS) Gasal mahasiswa pada Tahun Ajaran 2014/2015. Selain itu, juga dilakukan wawancara dengan mahasiswa dan diperoleh hasil bahwa pembelajaran Fisika Dasar lebih cenderung mengutamakan perumusan dibandingkan konsep. Akibatnya, mahasiswa cenderung lebih cakap mengerjakan soal menggunakan hafalan perumusan yang sudah ada dibandingkan menyelesaikannya secara konseptual dan terstruktur. Hal ini dapat menyebabkan terhambatnya proses pencapaian pembelajaran yang bermakna (meaningful learning).

Pembelajaran bermakna merupakan proses pengaitan antara informasi baru pada konsep-konsep relevan yang terdapat dalam struktur kognitif (Rusman, 2012: 252). Proses pembelajaran bermakna dapat menjadikan mahasiswa tidak hanya sekedar dapat menghafal konsep-konsep atau fakta-fakta saja, tetapi juga berusaha menghubungkan konsep-konsep tersebut untuk menghasilkan pemahaman yang utuh (Dirjen Dikti, 2005: 26). Apabila mahasiswa dapat mengetahui hubungan antar konsep maka konsep yang telah dipelajari dapat dipahami secara baik dan tidak mudah dilupakan.

Banyaknya materi yang harus dipelajari mengakibatkan dosen cenderung meminta mahasiswa untuk memecahkan suatu permasalahan fisika dengan cara cepat tanpa menjelaskan konsep dasarnya. Kondisi tersebut dapat mengakibatkan mahasiswa mengalami overloaded cognitive. Overloaded cognitive terjadi apabila mahasiswa terlalu banyak dibebani oleh proses-proses kognitif tanpa bisa mengontrol proses-proses tersebut. Menurut Kwon, dkk. (2011), overloaded cognitive dapat diatasi dengan memantau 
dan memilah-milah pengetahuan yang penerapan socratic dialogue juga dapat masuk pada saat bersamaan. Apabila menjadikan mahasiswa lebih aktif dalam mahasiswa dapat mengontrol pengetahuan- belajar, mengobservasi, mengumpulkan pengetahuan yang masuk, maka hasil data, dan menganalisis suatu permasalahan belajarnya akan menjadi lebih baik. Kwon fisika (Lam, 2011). Selain itu, socratic juga mengungkapkan bahwa hasil belajar dialogue juga mempermudah dosen dalam mahasiswa dikatakan berkualitas apabila mengidentifikasi mahasiswa yang mahasiswa secara sadar mampu mengalami miskonsepsi sehingga dapat mengontrol proses kognitif secara diarahkan pada konsep yang benar berkesinambungan sehingga dapat melatih (Wenning, 2006).

kemampuan dalam memecahkan Wortel \& Verweij permasalahan (problem solving). Oleh mengungkapkan bahwa socratic dialogue karena itu, dosen harus berusaha merupakan metode pembelajaran yang mengetahui dan menggali konsep lama dapat digunakan untuk memfokuskan yang telah dimiliki mahasiswa dan materi melalui pertanyaan-pertanyaan membantu memadukan konsep lama kritis. Pengajuan pertanyaan juga mahasiswa dengan pengetahuan baru yang merupakan salah satu indikator pengukuran akan diajarkan. Bantuan yang diberikan kemampuan berpikir mahasiswa (Yuliati, dosen kepada mahasiswa dapat dilakukan 2011: 18). Pertanyaan yang komunikatif dengan scaffolding. Melalui scaffolding, dapat membantu mengarahkan mahasiswa mahasiswa secara perlahan diberi tanggung untuk menggali pengetahuan yang telah jawab penuh terhadap proses belajarnya dimilikinya, sehingga dapat menemukan (Hitipeuw, 2009: 113). sendiri konsep yang benar (Wenning,

Metode pembelajaran yang dapat 2006).

memfasilitasi dosen untuk melakukan

Praktik socratic dialogue dalam scaffolding adalah socratic dialogue. pembelajaran menuntut dosen untuk Socratic dialogue merupakan metode mampu memilih jenis pertanyaan yang pembelajaran berbasis konstruktivisme tepat bagi mahasiswa. Pertanyaan yang untuk membangun dan mengembangkan baik membuat mahasiswa dapat melakukan kemampuan berpikir serta keaktifan aktivitas lebih dari sekedar mengingat berpendapat berkaitan dengan suatu strategi menjawab. Socratic questioning pengetahuan (Kingsley, 2011; Wenning, yang baik harus memiliki beberapa 2010). Lam (2011) juga menyatakan bahwa jawaban yang dapat diterima sehingga 
mengurangi kecenderungan mahasiswa untuk berhenti berpikir setelah mendapatkan satu jawaban yang benar (Saiki, 2008).

$$
\text { Paul \& Elder (2006: 20) }
$$

menyebutkan jenis-jenis pertanyaan yang dapat digunakan dalam socratic dialogue adalah sebagai berikut.

1. Pertanyaan untuk mengklarifikasi (question of clarification), yaitu

Apa yang kamu maksud dengan tekanan?

Apa poin utama dari jawabanmu?

Bagaimana proses tenggelamnya benda terkait dengan gaya angkat?

2. Pertanyaan yang menyelidiki tujuan (question that probe purpose), yaitu

Apakah tujuan dari mempelajari tekanan hidrostatis?

Apakah tujuan pemberian ruang kosong pada dek kapal?

Apakah tujuanmu ini dapat dibenarkan secara konseptual?

3. Pertanyaan yang menyelidiki asumsi (question that probe assumptions), yaitu Apa asumsimu pada topik ini? Apa asumsi lain sebagai gantinya? Apa yang menjadi dasar alasanmu?

4. Pertanyaan yang menyelidiki informasi, alasan, fakta, dan penyebab (question that probe information, reasons, evidence, and causes), yaitu
Apa yang dapat menjadi contoh peristiwa mengapung?

Apa alasanmu mengatakan bahwa massa jenis benda mempengaruhi gaya apung?

Apa informasi yang kamu butuhkan?

Bagaimana kalian dapat mengetahui bahwa hal itu benar?

5. Pertanyaan tentang sudut pandang atau perspektif (question about viewpoints or perspectives), yaitu

Apa yang kamu implikasikan terhadap fenomena tersebut?

Efek apa yang akan terjadi?

Jika itu terjadi, maka hal apa yang mungkin terjadi?

Apakah ada alternatif lain?

6. Pertanyaan yang menyelidiki implikasi dan konsekuensi (questions that probe implications and consequences), yaitu Bagaimana kita bisa mengetahui bahwa benda itu berada dalam kondisi mengapung atau melayang?

Apa pertanyaan tersebut mengasums ikan?

Bagaimana bisa seseorang menyelesaikan pertanyaan ini?

Apakah pertanyaan ini sulit untuk dijawab? Mengapa demikian?

7. Pertanyaan tentang pertanyaan (question about question), yaitu Apa yang menjadi inti dari pertanyaan ini? 
Mengapa kamu berpikir saya dapat dkk., 2009). Oleh karena itu, pembelajaran mengajukan pertanyaan ini? yang menggunakan socratic dialogue Apa artinya membuat pertanyaan? melibatkan peran aktif antara dosen dan

8. Pertanyaan yang menyelidiki konsep mahasiswa dalam menjelaskan suatu (question that probe concept), yaitu Apakah ide utama yang kita setujui? Mengapa ide tersebut penting?

Bagaimana ide/konsep ini dapat membimbing kemampuan berpikirmu ketika mencoba untuk mencari alasan penyelesaian permasalahan ini?

materi dan menganalisis prinsip yang terkandung di dalamnya. Selain itu, mahasiswa juga dibimbing untuk mencari solusi yang tepat dalam menyelesaikan permasalahan berkaitan dengan materi yang dibahas

Kemampuan

penyelesaian

9. Pertanyaan yang menyelidiki

kesimpulan dan interpretasi (question that probe inference and interpretation), yaitu

Solusi manakah yang kita perlukan?

Informasi manakah yang mendukung kesimpulan tersebut?

Bagaimana kamu dapat menemukan kesimpulannya?

Jenis-jenis socratic question yang telah dikaji dapat digunakan selama proses pembelajaran disesuaikan dengan tujuan dan kompetensi yang ingin dicapai oleh dosen. Pembelajaran dengan socratic dialogue menghadapkan mahasiswa permasalahan (problem-solving ability) merupakan kemampuan yang seharusnya dimiliki mahasiswa dalam pembelajaran fisika. Pembelajaran fisika tidak hanya menuntut mahasiswa untuk mengetahui dan memahami konsep-konsep fisika, tetapi juga menggunakan dan mengaplikasikan konsep-konsep tersebut untuk menyelesaikan suatu permasalahan. Problem solving merupakan upaya individu atau kelompok untuk menemukan jawaban berdasarkan pemahaman yang telah dimiliki sebelumnya. Jadi aktivitas problem solving diawali dengan dengan masalah-masalah ill-structured jawaban telah diperoleh sesuai dengan (real world problems). Pada proses kondisi masalah (Santyasa, 2009).

problem solving, mahasiswa menggunakan

Problem solving juga diartikan sejumlah keterampilan berpikir yang sebagai proses mental yang meliputi dipandu dengan socratic question. problem finding dan problem shaping Keadaan ini akan membentuk kebiasaan (Rokhmat, dkk., 2012). Problem finding berpikir dan bertindak aktif (Redhana, berarti penemuan masalah, sedangkan 
problem shaping berarti peninjauan ulang suatu pertanyaan sedemikian rupa sehingga proses solusi dapat dimulai atau dilanjutkan. Problem finding melibatkan aplikasi kreativitas sedangkan problem shaping sering melibatkan aplikasi berpikir kritis.

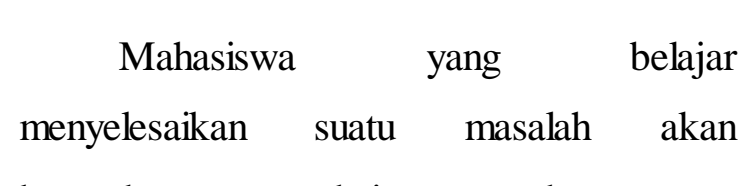
berusaha mengetahui pengetahuan yang diperlukan dan menerapkan pengetahuan yang dimilikinya (Dasna, dkk., 2007: 79). Kemampuan problem solving fisika meliputi kompetensi mahasiswa dalam (1) memperoleh strategi problem solving secara benar dan lengkap, (2) menggambarkan langkah-langkah problem solving, dan (3) memberikan alasan yang benar secara matematis disertai dengan bukti-bukti berupa prinsip, rumus atau perhitungan yang benar (Parwati, 2011:62).

Penilaian kemampuan problem solving dalam penelitian ini adalah mahasiswa mampu menyelesaikan masalah sesuai dengan pedoman tahapan penyelesaian masalah dan indikator seperti yang ditunjukkan pada Tabel 1 berikut.

Tabel 1. Tahapan dan Indikator Problem solving

\begin{tabular}{ll}
\hline \multicolumn{1}{c}{ Tahapan } & \multicolumn{1}{c}{ Indikator } \\
\hline Identifikasi & Menunjukkan \\
Masalah & fenomena yang ada \\
& dalam permasalahan \\
& dan merangkumnya \\
\hline
\end{tabular}

\begin{tabular}{ll}
\hline & dalam rumusan \\
masalah
\end{tabular}

Berdasarkan kajian teori yang telah dilakukan dan dukungan penelitian sebelumnya, diperoleh hasil yang baik tentang efektivitas penggunaan socratic dialogue dalam pembelajaran fisika. Oleh karena itu, perlu dilakukan proses pembelajaran untuk meningkatkan kemampuan problem solving mahasiswa sebagai calon guru melalui penggunaan metode socratic dialogue.

\section{METODE}

Penelitian yang digunakan adalah Penelitian Tindakan Kelas (PTK) sebagai upaya untuk memperbaiki atau meningkatkan kinerja dalam pembelajaran di kelas. Subjek dalam penelitian ini adalah 
mahasiswa Program Studi Pendidikan Dasar 1 semester ganjil tahun akademik Fisika kelas B angkatan 2014 yang sedang 2013/2014. Sedangkan observasi selama menempuh perkuliahan Fisika Dasar 1 pelaksanaan tindakan merupakan pada semester ganjil tahun ajaran pengamatan peneliti selama kegiatan 2014/2015. Penelitian dilakukan pada pembelajaran. Pengamatan tersebut matakuliah Fisika Dasar 1 Semester Ganjil meliputi keterlaksanaan pembelajaran dan 2014/2015 di Jurusan Fisika Universitas kemampuan problem solving mahasiswa Negeri Surabaya.

Prosedur penelitian diadopsi dari ketika berada di perkuliahan.

siklus penelitian tindakan kelas Kemmis dan Mc taggart yang tercantum dalam Sudjana (2005) dan dilakukan dalam dua siklus. Setiap siklus terdiri dari tahapan identifikasi masalah, perencanaan tindakan, pelaksanakan tindakan, observasi, dan refleksi.

Data nilai kemampuan problem solving diperoleh dari tes pada setiap akhir siklus, baik siklus I maupun siklus II. Peningkatan kemampuan problem solving dapat diketahui berdasarkan nilai rata-rata mahasiswa sebelum dan setelah dilakukan tindakan. Prosedur pengumpulan data yang digunakan dalam penelitian ini dilakukan dengan beberapa cara yaitu, observasi, dokumentasi, dan tes.

Observasi dalam penelitian ini terdiri dari observasi awal dan observasi selama pelaksanaan tindakan. Observasi awal bertujuan untuk mengetahui keadaan awal sebelum dilaksanakan tindakan. Data yang diperoleh pada observasi awal adalah nilai Tes digunakan untuk mengetahui sejauh mana kemampuan mahasiswa setelah mengikuti perkuliahan Fisika Dasar 1. Butir soal tes terdiri dari soal pilihan ganda dan uraian. Tes tersebut diberikan pada akhir setiap siklus (siklus I dan siklus II). Pada siklus I materi yang diujikan meliputi Fluida Statis, sedangkan materi yang diujikan pada siklus II adalah Fluida Dinamis.

Instrumen penelitian yang digunakan untuk memperoleh data dalam penelitian adalah instrumen pembelajaran dan instrumen pengukuran penelitian. Instrumen pembelajaran terdiri dari perangkat pembelajaran yang meliputi Satuan Acara Perkuliahan (SAP) untuk setiap siklus, LKM, dan media pembelajaran lain yang terkait dengan kelangsungan proses pembelajaran. Sedangkan instrumen pengukuran penelitian digunakan untuk mengetahui ketercapaian tujuan pembelajaran yang diinginkan, yaitu peningkatan kemampuan mahasiswa peserta perkuliahan Fisika 
problem solving mahasiswa melalui butir soal tes.

Nilai tes yang berupa butir soal uraian dijumlahkan sebagai skor total untuk setiap mahasiswa kemudian dirata-rata dihitung nilai hasil tes terhadap nilai ideal dari jumlah keseluruhan nilai ideal untuk setiap siklus.

Nilai tes $=\frac{\sum \text { nilai hasil tes }}{\sum \text { nilai hasil tes yang ideal }}$

(Sumber: Arikunto, 2006:240)

Perolehan nilai tes untuk setiap siklus akan dirata-rata sesuai dengan jumlah siklus yang dilaksanakan yaitu sebanyak 2 siklus. Hal ini diperlukan untuk mengetahui seberapa besar pemahaman mahasiswa tentang materi yang telah disampaikan. Mahasiswa dikatakan paham tentang materi yang telah disampaikan oleh dosen pengampu mata kuliah jika rata-rata hasil tes siklus I dan siklus II mencapai nilai 75 .

Penelitian ini dikatakan berhasil apabila nilai rata-rata kemampuan problem solving mahasiswa mencapai skor 75 . Selain itu, diharapkan jumlah mahasiswa yang nilainya mencapai skor 75 adalah sebesar $\geq 50 \%$. Apabila mahasiswa yang mencapai nilai target belum $\geq 50 \%$, maka tindakan yang dilakukan belum dikatakan berhasil dan masih perlu dilakukan ke siklus berikutnya. Indikator keberhasilan berlaku apabila terjadi peningkatan nilai pada tiap siklus. Apabila mahasiswa yang mencapai nilai target sudah mencapai $\geq$ $50 \%$ dan terjadi peningkatan nilai pada tiap siklus, maka tindakan yang diberikan dapat dikatakan berhasil dan dapat dihentikan.

\section{HASIL DAN PEMBAHASAN}

Penelitian diawali dengan kegiatan perencanaan yang meliputi observasi awal dan penyiapan perangkat pembelajaran. Observasi awal dilakukan dengan mengumpulkan data nilai pada pembelajaran Fisika Dasar 1 tahun sebelumnya. Setelah data awal terkumpul, kemudian menganalisis permasalahan yang timbul disertai dengan faktor penyebab permasalahan. Selanjutnya dilakukan fase tindakan berupa penerapan pembelajaran socratic dialogue.

Pelaksanaan socratic dialogue pada tiap pertemuan memiliki kuantitas yang berbeda. Hal ini bergantung pada materi dan permasalahan yang muncul untuk tiap pertemuan. Contoh socratic dialogue yang dilakukan yaitu,

Dosen

(Menampilkan tayangan video lava lamp yang merupakan contoh aplikasi hukum Archimedes)

(Sumber: http://science.wonderhowto.com/secret/inside-/lava-lamp)

“Apa sajakah fenomena yang ditemukan berdasarkan tayangan video?"

(question of probe information and evidence)

Mahasiswa :

"Lilin cair dalam lava lamp berbentuk bulat" 
"Bulatan lilin cair bergerak naik dan turun"

Dosen

"Mengapa lilin cair tersebut dapat berbentuk bulat?”(question that probe assumptions)

“Apakah lilin mendapat tekanan dari lingkungan di sekitarnya?"

"Siapakah yang memberi tekanan terhadap lilin cair tersebut?" (question that probe causes)

Mahasiswa

"Lilin mendapat tekanan dari cairan di sekitarnya. Hal ini disebabkan cairan memiliki tekanan hidrostatis yang arahnya menuju ke 1 titik sehingga lilin berbentuk bulat"

Dosen

"Mengapa bulatan lilin dapat bergerak ke atas?" (question that probe assumptions)

"Pada bagian bawah lava lamp terdapat lampu pemanas. Apa yang terjadi pada suatu zat jika dipanaskan?"

(question about perspectives)

Mahasis wa

"Zat tersebut akan memuai"

Dosen

"Saat suatu zat memuai, apakah zat tersebut mengalami perubahan?"

"Besaran fisika apakah yang berubah?" (question that probe information)

Mahasiswa :

"Volume zat membesar sehingga massa jenisnya menjadi lebih kecil"

Dosen

"Apa yang terjadi apabila massa jenis zat di dalam fluida lebih kecil dibandingkan massa jenis fluida?" (question about perspectives)

Mahasis wa

"Gaya angkat fluida bernilai besar sehingga zat atau benda tersebut dapat bergerak naik ke atas".

Socratic dialogue tidak hanya dilakukan dalam diskusi kelas, tetapi juga pada diskusi kelompok dengan bimbingan dari guru. Siswa dibimbing untuk menyelesaikan permasalahan melalui pertanyaan secara lisan maupun tertulis. Pembimbingan yang dilakukan pada diskusi kelompok dirasa lebih efektif karena hubungan antara dosen dan mahasiswa lebih dekat serta dapat menggali lebih dalam kemampuan mahasiswa. Kekurangannya adalah terletak pada ketersediaan waktu. Pembimbingan mahasiswa dalam bentuk kelompok menuntut dosen untuk memberikan porsi pertanyaan dan pengetahuan yang sama bagi tiap kelompok. Hal ini disebabkan pemerataan pengetahuan sehingga informasi yang diterima mahasiswa setara antara satu dengan yang lainnya.

Penerapan pembelajaran menggunakan socratic dialogue pada siklus I dilakukan dalam 2 kali pertemuan. Hal ini disebabkan mata kuliah Fisika Dasar 1 diajarkan 2 kali dalam seminggu dan bernilai 4 sks. Tiap pertemuan ditempuh dalam waktu 2 x 50 menit. Materi yang diajarkan pada siklus I adalah Fluida Statis yang meliputi konsep Tekanan, Tekanan Hidrostatis, Hukum Pascal, dan Hukum Archimedes. Pelaksanaan pembelajaran diakhiri dengan tes akhir siklus I yang berisi 10 soal pilihan ganda dan 2 soal uraian berkaitan dengan kemampuan problem solving fisika. Hasil dari tes akhir siklus digunakan sebagai 
indikator keberhasilan pelaksanaan keberhasilan. Proses pembelajaran tindakan. Berdasarkan hasil analisis data, diterapkan kembali dengan beberapa diperoleh rata-rata nilai tes mahasiswa perbaikan hasil dari refleksi pada siklus I. peserta perkuliahan Fisika Dasar 1 adalah Perbaikan yang dilakukan adalah sebesar 70,00. Skor ini belum memenuhi pengorganisasian waktu pelaksanaan indikator keberhasilan pembelajaran, pembelajaran sehingga tujuan dapat sehingga perlu dilanjutkan pada siklus II. tercapai tepat waktu sesuai dengan Terdapat beberapa hal yang mempengaruhi perencanaan pembelajaran Selain itu, skor tes akhir siklus I, diantaranya adalah, mahasiswa yang sebelumnya belum 1. Mahasiswa belum terbiasa dengan terbiasa dengan kegiatan socratic dialogue, sistem pembelajaran yang diterapkan di diberikan pelatihan pemecahan masalah kelas. Akibatnya mahasiswa masih dengan bantuan pertanyaan-pertanyaan memerlukan waktu untuk beradaptasi sehingga dapat beradaptasi dengan baik. dengan sistem pembelajaran tersebut. Materi yang diajarkan pada siklus II Hal ini tentunya dapat berdampak pada adalah Fluida Dinamis yang meliputi hasil belajar mahasiswa yang ditandai Fluida Ideal, Persamaan Kontinuitas, dengan tes kemampuan penyelesaian Hukum Bernoulli, dan aplikasinya. Seperti masalah. halnya siklus I, pelaksanaan pembelajaran

2. Kegiatan diskusi memerlukan waktu pada siklus II dilakukan sebanyak 2 kali yang lebih lama dari perencanaan dalam seminggu. Pada akhir pembelajaran, sehingga pembelajaran tidak mahasiswa diberikan tes untuk materi terlaksanan secara efektif Fluida Dinamis.

3. Pelaksanaan socratic dialogue belum berjalan secara maksimal.

Selain itu, jumlah mahasiswa yang memperoleh skor nilai > 75 belum sesuai dengan indikator keberhasilan yang telah ditetapkan. Jumlah mahasiswa dengan nilai > 75 adalah sebanyak 42,11\% dari jumlah total 38 mahasiswa.

Berdasarkan hasil analisis data, diperoleh nilai rata-rata tes kemampuan problem solving mahasiswa adalah mencapai skor 75,86. Nilai ini telah mencakup indikator keberhasilan yang ditetapkan, yaitu 75. Jumlah mahasiswa yang mencapai skor $>75$ adalah sebanyak $52,63 \%$ dari jumlah total 38 mahasiswa.

Penerapan socratic dialogue Pencapaian ini menunjukkan bahwa dilanjutkan pada siklus II karena hasil tes penelitian telah berhasil dan perlakuan pada siklus 1 belum memenuhi indikator dapat dihentikan. Perbandingan nilai hasil 
tes pada siklus I dan sikus II dapat dilihat berupa peningkatan kemampuan problem pada Gambar 1 berikut. solving fisika. Hal ini sesuai dengan pendapat Wenning (2010) bahwa socratic

Tes Kemampuan Penyelesaian Masalah

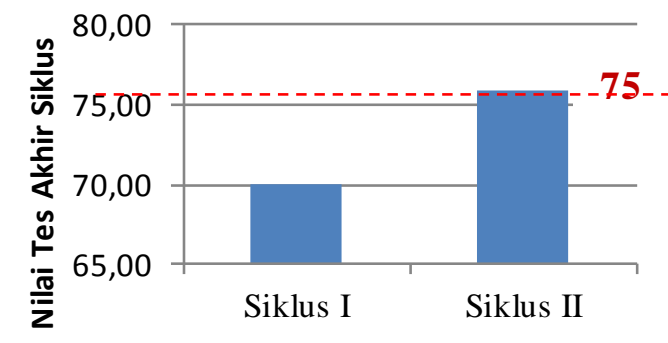

Gambar 1. Perbandingan Hasil Nilai Tes pada Siklus I dan Siklus II

Presentase jumlah mahasiswa yang memperoleh nilai > 75 pada siklus I dan siklus II dapat dilihat di Gambar 2 berikut.

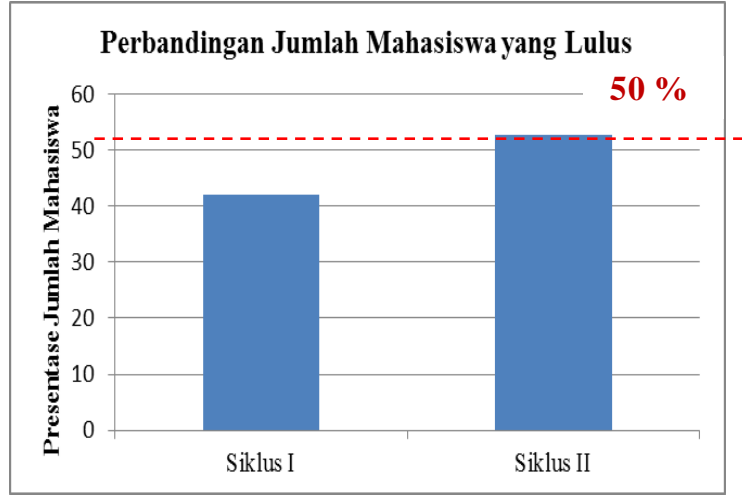

Gambar 2. Perbandingan Jumlah

Mahasiswa dengan Nilai > 75 pada Siklus I dan Siklus II

Perlakuan tindakan pembelajaran dengan menerapkan socratic dialogue memberikan dampak positif bagi kemampuan mahasiswa Program Studi Pendidikan Fisika Kelas B angkatan tahun 2014 yang sedang mengikuti perkuliahan Fisika Dasar 1. Dampak yang timbul adalah dialogue dapat mempermudah dosen dalam mengidentifikasi mahasiswa yang mengalami miskonsepsi sehingga dapat diarahkan pada konsep yang benar. Ketika mahasiswa telah memahami konsep dengan benar, maka kemampuannya dalam menyelesaikan suatu permasalahan terkait dengan bidang fisika juga akan menjadi lebih baik.

Hasil ini sangat dipengaruhi oleh peran aktif antara dosen dan mahasiswa selama pembelajaran berlangsung. Seperti yang diungkapkan oleh Taylor, dkk., (2012) bahwa pembelajaran dengan socratic dialogue melibatkan peran aktif antara dosen dan mahasiswa dalam menjelaskan suatu materi dan menganalisis prinsip-prinsip yang terkandung di dalamnya. Semakin aktif dosen dalam memberikan pertanyaan socratic sebagai scaffolding dalam menemukan suatu konsep atau solusi pemecahan masalah, maka akan semakin aktif mahasiswa dalam merespon/menjawab pertanyaan tersebut. Hasilnya, mahasiswa menjadi termotivasi untuk berpikir secara konstruktivis dalam menemukan solusi suatu permasalahan berdasarkan informasi yang diperoleh dari jawaban pertanyaan socratic dosen. Hal ini membuktikan pernyataan Kingsley (2011) 
yang mengungkapkan bahwa melalui pembelajaran dapat terlaksana secara socratic dialogue, mahasiswa dapat tepat.

dibimbing untuk berpikir konstruktivis b. Pada pelaksanaan pembelajaran dengan dengan menemukan hubungan antar pengetahuan. Melalui penemuan hubungan antar pengetahuan tersebut, mahasiswa menjadi lebih mudah dalam memecahkan suatu permasalahan.

\section{SIMPULAN}

Berdasarkan hasil analisis data dan pembahasan, maka kesimpulan dari penelitian adalah bahwa pembelajaran yang menggunakan socratic dialogue dapat meningkatkan kemampuan problem solving fisika mahasiswa calon guru fisika. Berdasarkan hasil tes akhir siklus I dan siklus I, nilai rata-rata tes kemampuan problem solving fisika mahasiswa mengalami peningkatan. Pada akhir siklus II, nilai rata-rata tes sudah memenuhi indikator keberhasilan, yaitu sebesar 75 .

Saran yang dapat diberikan berdasarkan hasil penelitian adalah,

a. Penerapan pembelajaran socratic dialogue memerlukan pengaturan waktu dan persiapan yang baik karena memiliki tahapan yang cukup banyak sehingga memerlukan waktu yang banyak pula. Selain itu, perlu pula diketahui kondisi mahasiswa saat pembelajaran, sehingga tahapan socratic dialogue perlu diperhatikan pemilihan jenis pertanyaan yang tepat bagi mahasiswa. Tidak semua mahasiswa dapat dengan mudah memahami pertanyaan-pertanyaan yang disampaikan oleh dosen. Oleh karena itu, sebaiknya pertanyaan dalam socratic dialogue disampaikan dengan bahasa yang mudah dipahami dan sesuai dengan tujuan yang hendak dicapai oleh dosen. Misalnya jika dosen ingin mengetahui pendapat mahasiswa mengenai suatu fenomena, maka dapat digunakan tipe-tipe pertanyaan dalam question that probe assumptions (pertanyaan yang menyelidiki asumsi).

c. Kuantitas penyajian socratic question baik secara lisan maupun tulisan harus disesuaikan dengan kebutuhan mahasiswa. Mahasiswa dapat menjadi terbebani dengan banyaknya pertanyaan yang diajukan oleh dosen. Penyajian pertanyaan yang berlebihan dapat menghambat kinerja mahasiswa, khususnya yang memiliki kemampuan berpikir tinggi, dalam menyelesaikan suatu permasalahan.

d. Perlu adanya pelatihan kemampuan bertanya baik untuk pengajar maupun peserta didik. Pemberdayaan 
kemampuan bertanya bagi dosen

berfungsi untuk meningkatkan

kreativitas

dalam

membimbing

mahasiswa agar berpikir aktif dan dapat menemukan sendiri konsep yang tepat pada suatu materi. Kemampuan bertanya bagi mahasiswa dapat melatih kemampuan berpikir serta bertindak pada saat pembelajaran berlangsung. Selain itu, mahasiswa yang telah terlatih dalam bertanya diharapkan dapat membantu mahasiswa lain yang masih memiliki kemampuan berpikir yang rendah dengan mengaplikasikan metode tutorial sebaya.

Perlu dilakukan penelitian sejenis pada materi, variabel yang diukur, dan jenjang pendidikan yang berbeda, untuk mengembangkan penerapan socratic dialogue.

\section{DAFTAR RUJUKAN}

Arikunto, S. (2006). Dasar-dasar Evaluasi Pendidikan. Jakarta: Bumi Aksara.

Dasna, I W., Sutrisno, Kamdi, W., AlHakim, S., Untari, S., Zubaidah, S., Amin, S., Herawati, I., Fajaroh, F., Yuwono, I., Sutarman \& Mahanal, S. (2007). Model-model Pembelajaran Inovatif. Malang: UM.

Dirjen Dikti. (2005). Tanya Jawab Seputar Kurikulum Berbasis Kompetensi (KBK) di Perguruan Tinggi. Jakarta:
Dirjen Dikti.

Hitipeuw, I. (2009). Belajar dan Pembelajaran. Malang: FIP UM.

Kingsley, P. (2011). The Socratic dialogue in Asynchronous online Discussions in Constructivism Redundant?. Campus-Wide Informations System, 28 (5). Emerald Group Publishing Limited.

Kwon, K., Kumalasari, C. D., \& Howland, J. L. (2011). Self-Explanation on Problem-Solving Performance in an Interactive Learning Environment. Journal of Interactive Online Learning, (Online), 10 (2):1-17, (http $/ / w w w . n c o l r . o r g / j i o l), \quad$ diakses 16 Mei 2014.

Lam, F. (2011). The Socratic Method as an Approach to Learning and its Benefits. Dietrich College Honors Theses Paper, 134 (Online), (http $/ /$ repository.cmu.edu/hsshonors /134), diakses 12 Februari 2014.

Parwati. (2011). Pembelajaran dan Jenis Masalah Terhadap Kemampuan Pemecahan Masalah pada Siswa SD yang Memiliki Sikap Berbeda Terhadap Matematika. Disertasi tidak diterbitkan. Malang : PSSJ. TEP.UM

Paul, R. \& Elder, L. (2006). The Thinker's Guide to The Art of Socratic Questioning,

(Online), 
(http://www.criticalthinking.org/TG

S_files/SocraticQuestioning

2006.pdf), diakses 18 November 2014.

Redhana, I. W., Sudiatmika, A. A. I. A. R.,

\& Artawan, I. K. (2009). Pengembangan Perangkat

Pembelajaran Berbasis Masalah dan Pertanyaan Socratik untuk Meningkatkan Keterampilan Berpikir Kritis Siswa SMP. Jurnal Pendidikan dan Pengajaran, 42 (3): 2.

Rokhmat, J., Setiawan, A., \& Rusdiana, D. (2012). Pengembangan PBK untuk Meningkatkan Kemampuan Problem solving Calon Guru Fisika. Yogyakarta: Prosiding Seminar Nasional Penelitian, Pendidikan dan Penerapan MIPA, Fakultas MIPA, Universitas Negeri Yogyakarta.

Rusman. (2012).

Model-Model

Pembelajaran: Mengembangkan Profesionalisme Guru. Jakarta: PT Raja Grafindo Persada.

Saiki, M. (2008). Socratic Teaching Method (A Textbook for: Socratic Questions 101), (Online), (http://www.msaiki.com/SOCRATE. 4W.pdf), diakses 18 November 2012. Santyasa, I. W. (2009). Pengembangan Pemahaman Konsep dan Kemampuan Pemecahan Masalah
Fisika bagi Siswa SMA dengan Pemberdayaan Model Perubahan Konseptual Berseting Investigasi Kelompok, (Online), (http $/ /$ www.freewebs.com/santyasa/ pdf2/PENGEMBANGAN_PEMAH AMAN_KONSEP.pdf), diakses 5 November 2012.

Sudjana, N. (2005). Penilaian Hasil Proses Belajar Mengajar. Bandung: PT Remaja Rosdakarya Offset.

Taylor, L., Cheer, U., Boister, N., Toomey, E., Mueller, S., \& Wilson, D. (2012). Improving The Effectiveness of Large Class Teaching in Law Degrees. New Zealand: Ako Aotearoa University of Canterbury.

Undang-Undang Republik Indonesia Nomor 14 Tahun 2005 tentang Guru dan Dosen. Direktorat Jenderal Pendidikan Tinggi. (Online), (http $/ / w w w . d i k t i . g o . i d / t a t a l a k s a n a / u$ pload/uu_14_2005.pdf), diakses 24 Agustus 2010).

Wenning, C. J. (2006). Engaging Student in Conducting Socratic dialogues:Suggestion for Science Teachers. Journal of Physics Teacher Education, 4 (1): 11.

Wenning, C. J. (2010). Levels of Inquiry Spectrum Learning Sequences to Teach Science, Journal of Physics Teacher Education, 5 (3): 14-16. 
Wortel, E. \& Verweij, D. (2008). Inquiry, Critism and Reasonableness: Socratic Dialogue as a Research Method?. Practical Philosophy, (Online), 9 (2), (http://society-forphilosophyinpractice.org/journal/pdf), diakses 07 Oktober 2012.

Yuliati, L. (2011). Kemampuan Berpikir Tingkat Tinggi. Disajikan dalam Workshop Peningkatan Kegiatan Belajar Mengajar di Perguruan Tinggi. Malang: LP3 UM. 